УДК $635.976(470.6)$

DOI 10.30679/2219-5335-2020-5-65-151-164

ПРОДУКТИВНОСТЬ

И КАЧЕСТВО ПЛОДОВ МУШМУЛЫ ГЕРМАНСКОЙ

В СРЕДНЕГОРЬЕ

ИНГУШСКОЙ РЕСПУБЛИКИ

Фисун Михаил Николаевич

д-р с.-х. наук, профессор

профессор кафедры садоводства

и лесного дела

Егорова Елена Михайловна

канд. с.-х. наук, доцент

доцент кафедры

общей агрономии

Канцалиева Залина Леоновна

канд. с.-х. наук, доцент

доцент кафедры экспертизы товаров

народного потребления

Федеральное государственное

бюджетное образовательное

учреждение высшего образования

«Кабардино-Балкарский

государственный аграрный

университет им. В.М. Кокова»,

Нальчик, Кабардино-Балкарская

Республика, Россия

Долгиев Мусса Русланович

заведующий лабораторией агрохимии

при кафедре агрономии

Федеральное государственное

бюджетное образовательное

учреждение высшего образования

«Ингушский государственныи

университет», Назрань,

Республика Ингушетия, Россия

Орография районов Центрального Предкавказья, обусловливает высокую степень разнообразия естественного состава растительности, в том числе плодовых дикоросов, обладающих пищевыми, лечебными, техническими,
UDC 635.976 (470.6)

DOI 10.30679/2219-5335-2020-5-65-151-164

\section{PRODUCTIVITY AND QUALITY \\ OF THE FRUITS \\ OF GERMAN'S MUSHMULA \\ IN THE MIDDLE MOUNTAINS \\ OF THE INGUSH REPUBLIC}

Fisun Mikhail Nikolaevich

Dr. Sci. Agr., Professor

Professor of the Department

of Horticulture and Forest Business

Egorova Elena Mikhailovna,

Cand. Agr. Sci., Docent

Associate Professor

of General Agronomy Department

Kantsalieva Zalina Leonovna

Cand. Agr. Sci., Docent

Associate Professor of the Expertise

Consumer Goods Department

Federal State Budgetary

Educational Institution

of Higher Education

"Kabardino-Balkarian

State Agrarian University

named after V.M Kokova»,

Nalchik, Kabardino-Balkarian

Republic, Russia

Dolgiev Mussa Ruslanovich

Head of Agricultural Chemistry

Laboratory at the Agronomy Department

Federal State Budgetary

Educational Institution

of Higher Education

"Ingush State University»,

Nazran, Ingushetia Republic,

Russia

The orography of the Central Ciscaucasia regions, determines a high degree of diversity of the natural composition of vegetation, including fruit wild plants with nutritional, medicinal, technical, perfumery properties and many 
парфюмерными свойствами и множеством других хозяйственно значимых признаков. В этом плане, особое место занимает исключительно разнообразная по геогидрологическим условиям полоса среднегорного пояса с высотными отметками 500-1200 метров над уровнем моря. Ввиду значительной удаленности региона Центрального Предкавказья от Черноморского бассейна с Запада и от Каспийского - с Востока, здесь сложился своеобразный комплекс из древесных и кустарниковых растений с обилием эндемичных видов плодовых дикоросов представляющих важный ресурс для получения разнообразной по качеству и оригинальной по биохимическому составу продукции. В данной статье изложены методические аспекты изучения естественных зарослей плодовых дикоросов, выявлены и представлены основные показатели для оценки продуктивности и качества урожая растений мушмулы. Приведены характерные особенности зарослей и отдельных растений для выделения из них побегов, обладающих ценными хозяйственными свойствами. В результате проведенных исследований установлены: влияние отдельных элементов ландшафтов - высотного пояса и экспозиции склонов на обилие растений мушмулы германской в естественных сообществах древесных и кустарниковых пород, а также продуктивность и морфологические показатели плодов мушмулы, в том числе обладающих признаками клоновости. Выявлена зависимость выхода саженцев от видовых особенностей подвоев. Сохранение естественных зарослей и введение в культуру мушмулы германской позволяет решить социально-экономические вопросы современного садоводства в регионах Центрального Предкавказья.

Ключевые слова: СРЕДНЕГОРНЫЙ ПОЯС, РАСТИТЕЛЬНЫЕ РЕСУРСЫ, МУШМУЛА ГЕРМАНСКАЯ, ПРОДУКТИВНОСТЬ, КАЧЕСТВО ПЛОДОВПЛОДОВ other economically significant signs.

In this regard, a special place is occupied by a strip of the mid-mountain belt with altitudes of 500 - 1200 meters above sea level, which is extremely diverse in terms of geohydrological conditions. Due to the considerable remoteness of the Central Ciscaucasia Region from the Black Sea basin from the West and from the Caspian - from the East, a peculiar complex of tree and shrub plants with an abundance of endemic species of fruit wild plants has developed here, which are the important resource for receiving of quality and original on biochemical composition production. The methodological aspects of the study of natural thickets of fruit wild plants are presented and the main indicators for assessing the productivity and quality of the medlar harvest are revealed and presented in this article. The characteristic features of thickets and individual plants are given for the isolation of protoclone shoots from them, which have valuable economic properties. As a result of the studies carried out, it was established: the influence of individual landscape elements like height bend and slope exposure the abundance of German medlar plants in natural communities of tree and shrub species, as well as productivity and morphological indicators of fruits, including those with signs of cloning. The dependence of the yield of saplings on the species characteristics of rootstocks is revealed. The preservation of natural thickets and the introduction of the Germanic medlar in culture allows us to solve the social-economic issues of modern gardening in the regions of the Central Ciscaucasia.

Key words: MID-MOUNTAIN BELT, PLANT RESOURCES, GERMAN MEDLAR, PRODUCTIVITY, QUALITY OF FRUITS 
Введение. Ингушетия как автономный административный регион Северного Кавказа образован в 1992 году [1] и представляет собой территорию со сложными орографическими и разнообразными ландшафтными условиями, в пределах которых возможно ведение различных отраслей сельского хозяйства [2-4]. Так, в степной зоне, ограниченной высотным поясом в 300-550 метров над уровнем моря, рельеф которой представлен слабонаклонной и/или волнистой равниной северной и северо-восточной экспозиции, подверженной влиянию сухих восточных ветров, складываются аридные условия с высоким уровнем теплообеспеченности, в которых земледелие носит поливной характер.

Ландшафты нижнего горного пояса республики в высотном поясе 550-700 метров представляют собой населенные пункты и лишь небольшими массивами по 150-400 гектаров, используются в качестве пахотных угодий. Территории с высокими, до 1000-1200 м отметками, составляют среднегорный пояс, в пределах которого произрастает множество (свыше 25) видов дикоплодовых древесных и кустарниковых растений, обладающих ценными хозяйственными свойствами: кизил мужской, мушмула германская, калина обыкновенная, яблоня лесная, облепиха крушиновая, боярышник, груша, ирга, кизильник, шиповник и др. $[1,2,5,6]$.

Практически все виды плодовых дикоросов отличаются богатым биохимическим составом, значительным содержанием биологически активных веществ и широко используются местным населением в качестве пищевых и лекарственных продуктов [7-15].

В среднегорном поясе Ингушетии, наибольшим биоразнообразием отличаются заросли мушмулы германской, кизила мужского и облепихи крушиновой, произрастающие куртинами или одиночными кустами. Ввиду формирования более крупных плодов, их повышенной устойчивости к механическим нагрузкам, лучших пищевых достоинств, доступности сбора урожая в местах произрастания в районе среднего горного пояса, мушмула 
обладает рядом преимуществ перед кизилом и облепихой и представляется перспективным растением для широкого хозяйственного использования, в том числе в культуре [16, 17].

Изучение распространения и особенностей биологии естественного генофонда мушмулы в условиях среднегорного пояса республики Ингушетии отвечает потребностям современного состояния отрасли садоводства, социальным запросам ведения плодоводства на инновационной основе, промышленного производства экологически безопасной продукции, пригодной для конкуренции на внутреннем и внешнем рынках, является актуальной задачей сельского хозяйства региона. В виду того, что плоды мушмулы обладают сравнительно длительным сроком их пригодности для сбора и переработки (в течение сентября-декабря) с получением ценной продукции, представляется возможным сбор урожая в естественных зарослях, а также создание эксплуатационных плантаций из крупноплодных форм [18-20].

Высказанное положение послужило основанием для определения цели исследований: изучить ресурсный потенциал естественных зарослей мушмулы германской, выявить ее продуктивность в условиях среднегорных ландшафтов, установить особенности изменения структуры кустов с учетом формирования клонов, перспективных для введения в культуру.

Объекты и методы исследований. Объектами исследований являлись естественные заросли и культурные насаждения мушмулы, произрастающей отдельными куртинами и одиночно на покатых склонах северо-восточной и юго-западной экспозиций, разрезанных овражной сетью в высотном поясе 500-1000 метров над уровнем моря. Важно, что естественные заросли, подлежащие изучению, расположены в густонаселенном районе среднего и нижнего горных поясов и доступны для сбора и транспортировки плодов к местам их потребления и переработки. 
Глубина оврагов колеблется от 1-1,5 м в верхней и до 11-14 м в нижней части. Длина тальвега балок достигает 80-170 метров. Берега и тальвег балок заросли кустарниковой растительностью, в том числе мушмулой германской, обилие которой установлено в процессе исследований путем учета количества кустов на 100 метров поперечного сечения трассы оврагов с пересчетом на 1 гектар проективной площади. Расстояние между смежными трассами составляло 20 метров. Концевые точки трасс отмечены хорошо видимыми вешками красного цвета высотой до 3 метров.

Обилие мушмулы определяли в процентном отношении численности ее особей к общему числу кустарниковых растений, в среднем на 100 погонных метров каждого трассированного хода, в перпендикулярном направлении к оси тальвега оврагов.

Для выявления степени и характера развития растений мушмулы учитывали их структуру (по количеству побегов, отрастающих от головы кустов с урожаем и без плодов), их диаметр на высоте 25 см от поверхности почвы, высоту самых высокорослых побегов. Отмечали сроки цветения, начала образования завязи, массового созревания плодов. В последний период учитывали урожайность кустов. Для характеристики морфологических и хозяйственных свойств плодов учитывали их среднюю массу, определяли выход сока. Сок мушмулы анализировали на содержание растворимых углеводов и питательных органических и минеральных веществ, в том числе микроэлементов и биологических активных соединений, преимущественно фенольной природы.

Указанные показатели свойств плодов мушмулы изучали на объектах естественного происхождения и в культурных насаждениях на приусадебных участках жителей г. Назрань и селения Барсуки. Биохимические анализы выполнены в лаборатории Россельхозцентра КБР. По каждому из объектов, объем выборки составлял минимум 30 экземпляров. Достоверность 
различий в параметрах изучаемых объектов определена статистической обработкой по величине наименьшей существенной разницы, вычисленной по $t$-критерию Стьюдента.

Обсуждение результатов. В результате проведенных учетов и измерений выявлены качественные и количественные различия в структуре кустов, достигающие существенных значений, обусловленных генотипическими и фенотипическими свойствами растений мушмулы (табл. 1).

Таблица 1 - Структура кустов мушмулы в естественных зарослях и их обилие в среднегорном поясе на территории Республики Ингушетии (по материалам учетов за 2018-2019 гг.)

\begin{tabular}{|c|c|c|c|c|c|c|c|c|c|}
\hline \multicolumn{2}{|c|}{$\begin{array}{c}\text { Элементы } \\
\text { рельефа }\end{array}$} & \multicolumn{2}{|c|}{$\begin{array}{c}\text { Количество } \\
\text { кустов }\end{array}$} & \multirow{2}{*}{ 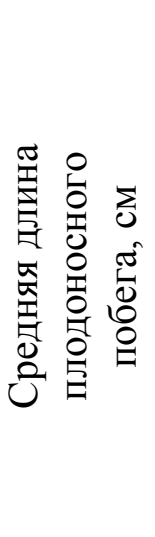 } & \multicolumn{2}{|c|}{$\begin{array}{c}\text { Среднее } \\
\text { количество } \\
\text { побегов } \\
\text { в кусте, } \\
\text { шт }\end{array}$} & \multirow{2}{*}{ 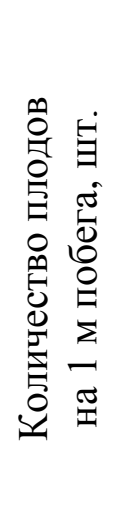 } & \multirow{2}{*}{ 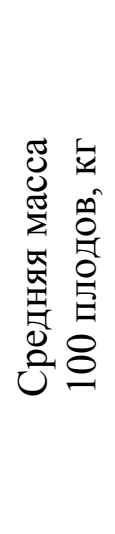 } & \multirow{2}{*}{ 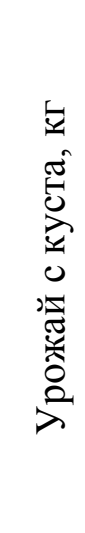 } \\
\hline 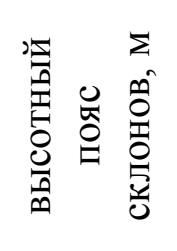 & 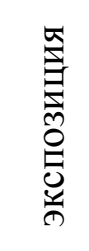 & $\begin{array}{l}0 \\
\grave{D} \\
\stackrel{\infty}{0}\end{array}$ & 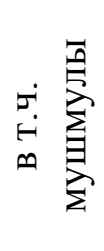 & & O্ & $\begin{array}{l} \\
\\
\end{array}$ & & & \\
\hline \multirow{2}{*}{$500-600$} & $\mathrm{CB}$ & 484 & 145 & 37 & 72 & 60 & 44 & 0,77 & 3,16 \\
\hline & Ю3 & 572 & 166 & 25 & 84 & 78 & 48 & 0,63 & 2,92 \\
\hline \multirow{2}{*}{$600-700$} & $\mathrm{CB}$ & 308 & 109 & 28 & 66 & 55 & 38 & 0,68 & 2,88 \\
\hline & Ю3 & 418 & 152 & 22 & 76 & 62 & 36 & 0,59 & 2,61 \\
\hline \multicolumn{2}{|c|}{$\mathrm{HCP}_{05}$} & & 31 & 7 & 9 & 11 & 4 & 8 & 0,21 \\
\hline
\end{tabular}

Анализ приведенных в таблице данных показывает, что в обоих высотных поясах в составе зарослей кустарников мушмула занимает доминирующее положение на склонах юго-западной экспозиции. При этом обилие мушмулы на северо-восточных склонах в высотном поясе 500-600 метров существенно больше, чем на высоте 600-700 метров. На юго-западном 
склоне в обоих поясах обилие кустов мушмулы находится в одном доверительном интервале: то есть существенное влияние экспозиции склонов на обилие кустов мушмулы проявляется в большей степени в высотном поясе 600-700 метров, чем на 100-200 метров ниже.

В естественных зарослях среднегорного пояса по уровню и срокам потребления свежих и переработанных плодов местным населением, выделяется мушмула германская, кусты которой распространены преимущественно на участках с мощностью суглинистого (глинистого) почвенного покрова свыше 30-40 см и образуют групповые заросли, в куртинах которых размещаются до 10-ти и больше разновозрастных растений. Характерной особенностью мушмулы, произрастающей в естественных условиях и в культуре, является формирование плодов из одиночных цветков, на концах побегов текущего года (рис. 1).

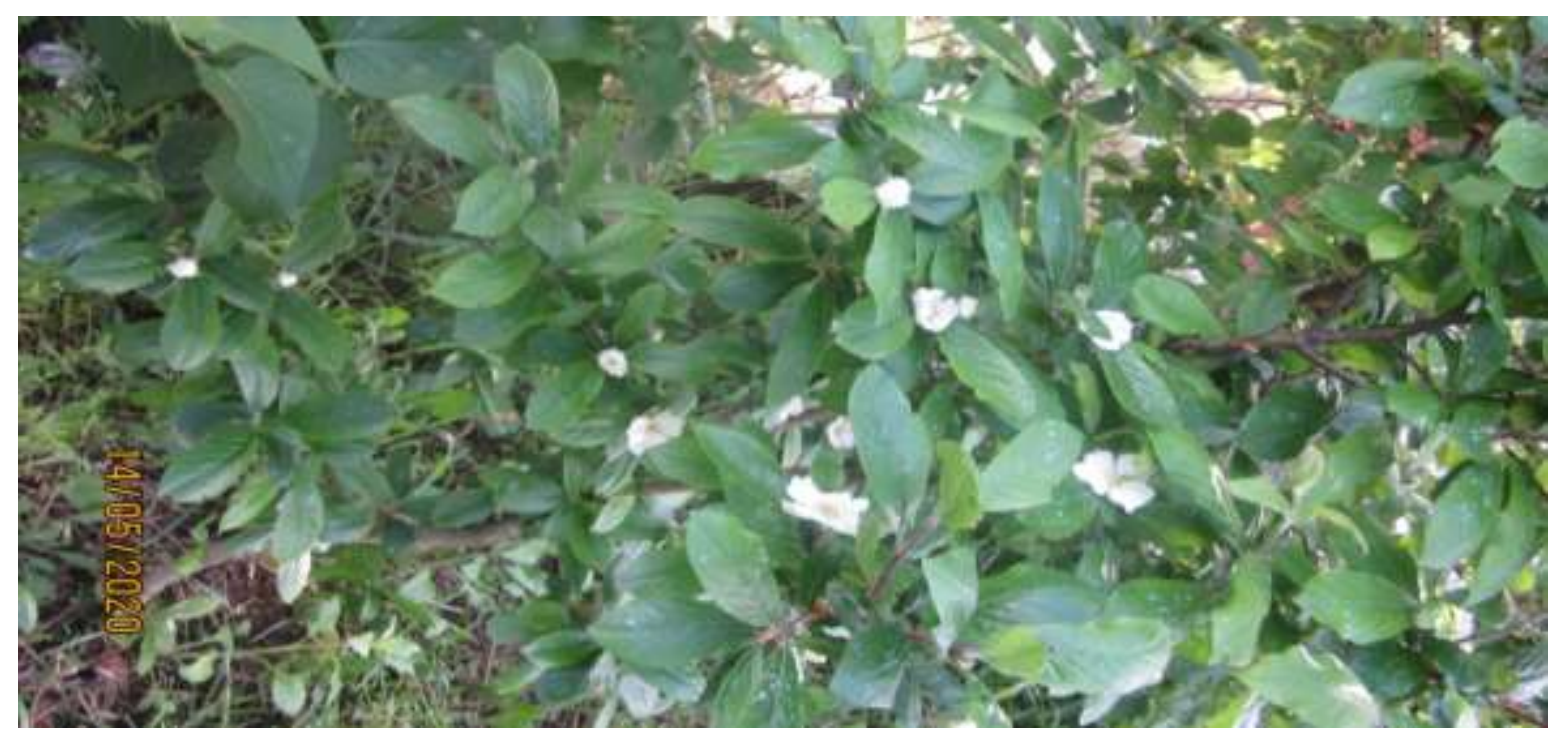

Рис. 1. Одиночные цветки мушмулы на плодоносном побеге

За годы учетов фенологии развития растений мушмулы отмечены сроки начала цветения 8-14 мая 2020 года и 16 мая-6 июня 2018 года. Особенность развития генеративных органов, связанная с длительным сроком 
Плодоводство и виноградарство Юга России № 65(5), 2020 г.

цветения, а в последующем и созревания плодов, в значительной степени определяется высотным поясом места произрастания зарослей. Так, длительность периода от начала до окончания цветения мушмулы в зарослях на высоте 500-600 метров составляет 18-22 дня и на высоте 600-700 метров20-25 дней. За столь длительный срок цветения неизбежно бывают дни с сухой солнечной погодой, что благоприятно сказывается на опылении цветков насекомыми, главным образом, пчелами, и на формировании плодов с полноценными семенами.

Для выделения клонов мушмулы проводили учет количества побегов, произрастающих из основания головы кустов. При этом выделяли побеги старше 3-х лет (диаметром свыше 1,5 см на уровне первого снизу разветвления), на которых учитывали число цветков на однолетних ветках. По соотношению количества плодов к длине плодоносящей части побегов определяли их плодоносность в расчете на 1 метр прироста.

Из числа собранных плодов дважды (15-20 сентября и 10-15 января) отбирали образцы для определения их биохимических и морфологических свойств. Побеги форм мушмулы, выделенные по плодоносности, средней массе плодов и биохимическим показателям, были размножены на подвое сеянцев айвы для последующего изучения.

В результате проведенных исследований установлено, что выделенные побеги формируются преимущественно в кустах, у которых свыше 20 побегов. Из числа обследованных плодоносящих растений только у 6 кустов из 208 обследованных, с количеством побегов 22,7-31,4, выявлены побеги с массой 100 плодов свыше 1 кг, что существенно превосходит массу плодов на побегах типичных кустов. То есть по средней массе плодов такие побеги могут быть выделены как клоновые для дальнейшего изучения. Ввиду того, что кусты с клоновыми побегами произрастают в однотипных условиях, изменения массы плодов нельзя отнести к фенотипическим. 
Плодоводство и виноградарство Юга России № 65(5), 2020 г.

Данные морфологических (рис. 2 а, б) и биохимических (табл. 2) анализов свидетельствуют о существенно более высоких значениях средней крупности и выхода сока из плодов, сформировавшихся на клоновых побегах, чем на типичных.

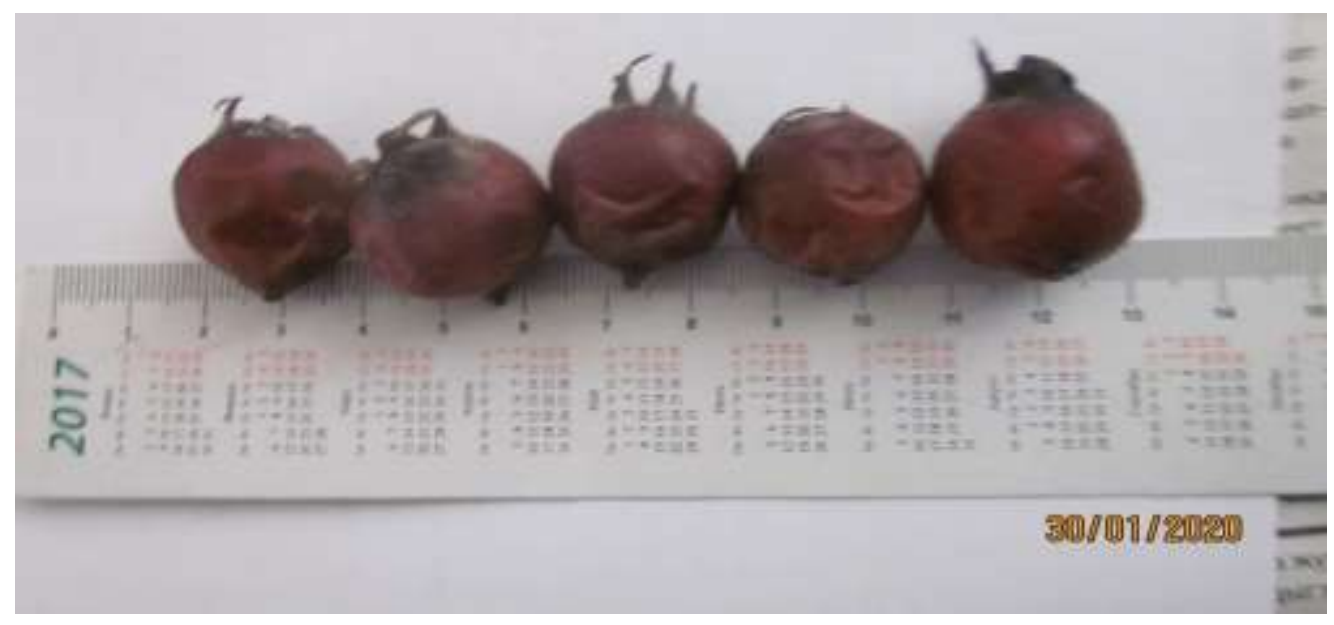

Рис. 2 а. Плоды мушмулы из типичных побегов (средний диаметр = 1,8 мм)

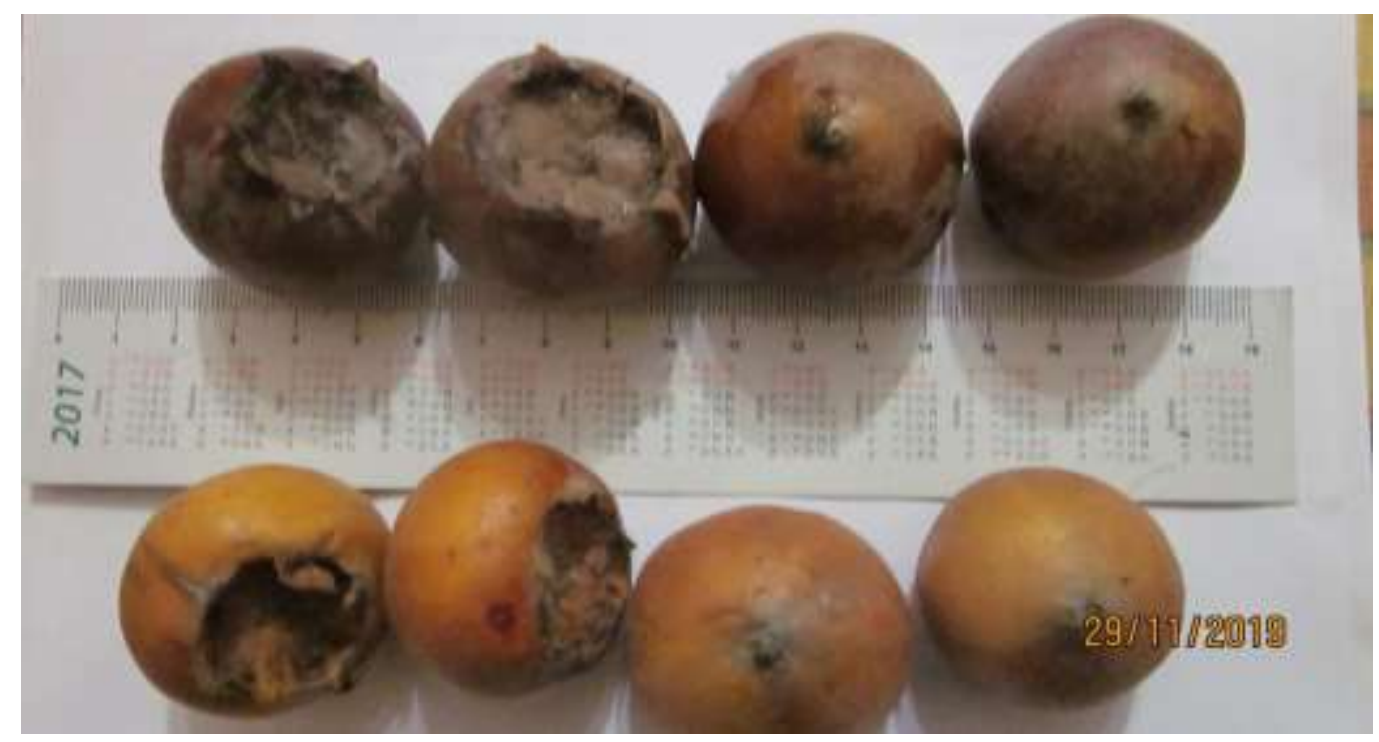

Рис. 2 б. Плоды мушмулы из клоновых побегов (средний диаметр = 3,8мм)

Повышение выхода сока в образцах плодов после их выдержки на слабом морозе связано с потерей влаги из кожицы и увеличением отделяемости мякоти от семян и внутренней части наружного покрова 
(в сумме на 3,0-4,5 \%). Наблюдается устойчивая тенденция большего содержания в соке плодов типичных побегов сахаров и меньшего кислот, чем в соке плодов отобранных экземпляров. Отмеченная ситуация связана с большей массой плодов на выделенных в отбор побегах и снижением концентрации сока в крупных плодах по сравнению с мелкими. Такая закономерность подтверждается данными содержания титруемых кислот, в том числе витамина С в соке (по ГОСТ 34151-2017), особенно наглядно проявляющаяся в первый срок сбора урожая.

\section{Таблица 2 - Биохимическая характеристика сока плодов мушмулы германской}

(средние показатели на 10-15 сентября и 2-5 декабря 2017-2019 гг.)

\begin{tabular}{|c|c|c|c|c|c|c|c|c|}
\hline \multirow{3}{*}{$\begin{array}{c}\text { Срок } \\
\text { измерения }\end{array}$} & \multirow{2}{*}{\multicolumn{2}{|c|}{ Выход сока, \% }} & \multirow{2}{*}{\multicolumn{2}{|c|}{$\begin{array}{c}\text { Содержание } \\
\text { растворимых } \\
\text { углеводов } \\
\text { в соке, г/дм }\end{array}$}} & \multicolumn{4}{|c|}{ Содержание кислот в соке, г/дм ${ }^{3}$} \\
\hline & & & & & \multicolumn{2}{|c|}{ всего } & \multicolumn{2}{|c|}{$\begin{array}{c}\text { в т.ч. } \\
\text { витамина С, } \\
\text { мг/дм }{ }^{3}\end{array}$} \\
\hline & $*$ & $* *$ & $*$ & $* *$ & $*$ & $* *_{-}$ & $*$ & $* *$ \\
\hline $10-15.09 / 2017$ & 21.6 & 32.7 & 6.6 & 6.4 & 5.3 & 5.5 & 7,7 & 8.4 \\
\hline $2-5.12 / 2017$ & 22.3 & 31,4 & 12.8 & 12.5 & 4,4 & 4.7 & 5,8 & 6.2 \\
\hline $10-15.09 / 2018$ & 20.8 & 31.5 & 7.3 & 7.1 & 5.1 & 5.3 & 7,1 & 8.7 \\
\hline $2-5.12 / 2018$ & 21.2 & 30,7 & 13.5 & 13.4 & 4.2 & 4.4 & 5,6 & 6.4 \\
\hline $10-15.09 / 2019$ & 26.4 & 34.5 & 7.4 & 7.0 & 5.3 & 5.4 & 7,3 & 8.6 \\
\hline $2-5.12 / 2019$ & 26.6 & 32,8 & 14.2 & 13.9 & 3.9 & 4.1 & 5.5 & 6.5 \\
\hline $10-15.09 .2017-19$ & 22.9 & 32.9 & 7,1 & 6,8 & 5.2 & 5.4 & 7.4 & 8.6 \\
\hline $2-5.12 .2017-19$ & 23.4 & 31,8 & 13,5 & 13,3 & 4.2 & 4.4 & 5.6 & 6.4 \\
\hline
\end{tabular}

Примечание: *типичные плоды; ** плоды на выделенных в отбор побегах

В процессе исследований выявлено, что биохимический состав плодов мушмулы в значительной степени определяется условиями вегетации. Так, в 2019 году, благодаря обилию осадков в июле и первой половине августа, когда идет активное созревание плодов, их средняя масса и выход сока оказались на 1,8-2,4 \% больше, чем в тот же срок двух предыдущих лет. Устойчивый тренд различий анализируемых показателей между типичными и отобранными по морфологическим и биохимическим характеристикам плодов 
Плодоводство и виноградарство Юга России № 65(5), 2020 г.

побегами позволяет выделить формы для дальнейшего углубленного изучения. При этом заметно, что вероятность формирования перспективных форм увеличивается по мере нарастания показателя кустистости растений (табл. 3).

Таблица 3 - Количество типичных и содержащих выделенные в отбор побеги кустов мушмулы в существующих естественных зарослях

у города Назрани (данные учетов за 2017-2019 гг.)

\begin{tabular}{|l|c|c|}
\hline \multicolumn{1}{|c|}{ Признаки } & \multicolumn{2}{c|}{ Показатели признаков } \\
\cline { 2 - 3 } & шт. & $\%$ \\
\hline Всего кустов на участке & 407 & 100 \\
\hline Количество кустов с выделенными в отбор побегами & 11 & 2,7 \\
\hline $\begin{array}{l}\text { Кустистость типичных растений } \\
\text { (количество плодоносных побегов в кусте) }\end{array}$ & 65 & 100 \\
\hline $\begin{array}{l}\text { Среднее количество выделенных в отбор побегов } \\
\text { в одном кусте }\end{array}$ & 29 & 44,6 \\
\hline $\begin{array}{l}\text { Плодоносность типичных побегов } \\
\text { (количество цветков на 1 м побега текущего года) }\end{array}$ & 33 & - \\
\hline $\begin{array}{l}\text { Плодоносность выделенных в отбор побегов } \\
\text { (количество цветков на 1 м побега текущего года) }\end{array}$ & 47 & - \\
\hline
\end{tabular}

Решение вопроса о хозяйственном использовании урожая мушмулы достигается путем внедрения системы выращивания посадочного материала. При этом важную роль играет выбор подвоев и создание маточников привойного (из выделенных клоновых форм) материала. В качестве подвоя для мушмулы чаще всего используются сеянцы айвы и груши и реже - боярышника. У первых двух растений всхожесть семян достигает 85-93 \%. Изза прочной скорлупы, покрывающей эндосперм семян мушмулы и боярышника, их всхожесть без предварительной обработки не превышает 30-50 \%.

Нами изучено выращивание сеянцев мушмулы из типичных мелких плодов и укорененных черенков из порослевых побегов. Посев костянок мушмулы и боярышника, заготовленных из мелких плодов, проводили после их высушивания до влажности 13-15 \% и последующей скарификации путем механической обработки наждачной бумагой. Отмечается, что повышение всхожести семян мушмулы достигается также путем их выдержки в 
кипящей воде в течение 1-2 минут или в концентрированной серной или соляной кислоте 3-5 минут.

Выявлено, что лучшими подвоями для крупноплодных форм являются двулетние сеянцы мушмулы, достигшие толщины штамбика 6-8 мм на высоте 5-7 см от поверхности почвы (табл. 4).

Таблица 4 - Параметры двухлетних саженцев мушмулы в зависимости от вида подвоев

\begin{tabular}{|c|c|c|c|c|c|}
\hline \multirow[b]{2}{*}{ Виды подвоев } & \multirow{2}{*}{$\begin{array}{c}\text { Выход } \\
\text { саженцев, } \\
\%\end{array}$} & \multirow{2}{*}{$\begin{array}{c}\text { Прирост } \\
\text { за первый } \\
\text { год } \\
\text { вегетации, } \\
\text { м }\end{array}$} & \multicolumn{2}{|c|}{ Урожай с дерева } & \multirow{2}{*}{$\begin{array}{c}\text { Сохранность } \\
\text { саженцев } \\
\text { на 4-ый год } \\
\text { вегетации, } \\
\%\end{array}$} \\
\hline & & & Кг & $\begin{array}{c}\text { в \% } \\
\text { к контролю }\end{array}$ & \\
\hline $\begin{array}{l}\text { Мушмула, } \\
\text { укорененные черенки, } \\
\text { контроль }\end{array}$ & 82,2 & 0,51 & 0,12 & 100 & 91,6 \\
\hline Мушмула, сеянцы & 77,6 & 0,46 & 0,09 & 75,0 & $94,1 *$ \\
\hline Айва, сеянцы & $75,2 *$ & $0,41 *$ & $0,04 *$ & 33,3 & 92,3 \\
\hline Груша, сеянцы & 80,3 & 0,49 & 0,11 & 91,7 & $95,3 *$ \\
\hline Боярышник, сеянцы & $73,8 *$ & $0,38 *$ & $0,06^{*}$ & 50,0 & 91,0 \\
\hline $\mathrm{HCP}_{05}$ & 4,8 & 0,09 & 0,05 & - & 2,4 \\
\hline
\end{tabular}

Примечание: *отмечены значения, существенно отличные от показателей контрольного варианта

Для создания насаждений из мушмулы следует использовать саженцы, которые целесообразно размещать в один-два ряда по границам участков землепользования с расстоянием между растениями 1,0-1,5 м. Ввиду раннего (на второй год) вступления в плодоношение формирование кустов мушмулы следует начинать с первого года вегетации, преимущественно путем укорачивания сильнорастущих побегов. Лучший срок обрезки - после осеннего сбора урожая (середина октября-вторая декада ноября).

Заключение. В результате проведенных исследований установлено влияние отдельных элементов ландшафтов на обилие растений мушмулы германской в естественных сообществах древесных и кустарниковых пород. 
Плодоводство и виноградарство Юга России № 65(5), 2020 г.

Определены продуктивность и морфологические характеристики плодов, выявлены основные показатели для оценки продуктивности и качества урожая мушмулы. Следует указать, что введение в культуру мушмулы германской позволяет решить ряд экономических вопросов садоводства в регионах Центрального Предкавказья.

\section{Литература}

1. Природно-климатические ресурсы Ингушетии. Нальчик: Эль-Фа, 2002. 224 с.

2. Гудковский В. А. Проблемы и перспективы обеспечения свежими фруктами и повышения состояния здоровых людей / История, современность и перспективы развития садоводства России. М., 2000. С. 38-45.

3. Канцалиева 3.Л. Дикоплодовые растения горной зоны Центрального Предкавказья. М.: АН3, 2009. С. 42-43

4. Концепция устойчивого развития сельских территорий Российской Федерации на период до 2020 года: утверждена распоряжением Правительства РФ от 30 ноября 2010 г. № 2136-р // Информационно-правовой портал ГАРАНТ.РУ. Режим доступа: http://baze.garant.ru/2073544. 592 c.

5. Витковский В.Л. Плодовые растения мира. СПб., М., Краснодар: Лань. 2003.

6. Жуковский П.М. Культурные растения и их сородичи. Л.: Колос, 1971. 751 с.

7. Jamal T., Gets D. Collaboration theory and community tourism planning // Annals of Tourism Research. № 22. - 2009. P. 144-147.

8. Асадов К.С. Дикорастущие плодовые деревья и кустарники северо-восточной части Азербайджана // Растительные ресурсы. Т. 15. Вып. 4. 1979. С. 527-531.

9. Beni M.C. Polinica e Estraegia do desenvolvimento regional: planejamento integrado e sustentavel do turismo // Turismoem Analise. №10. - 1999. p. 216 - 218.

10. Растительные ресурсы СССР: цветковые растения, их химический состав, использование; Семейства Hydrageacae - Haloragacea. Л.: Наука. 1987. 328 с.

11. Mc Kinion J.M. Dinamic simulation: a positive feedback mechanism for experimental research in the biological sciences/ Agricult. Syst.- 1980. - V. 5. № 4. - P. 72-74.

12. Работнов А.Т. Фитоценология. М.: МГУ, 1985. 296 с.

13. Alexander M. Soil microbiology in the next 75 years: fixed, flexible or mutable. Soil science jornal. 1991. - V. 151- №1. P.186-192.

14. Hartwell I.L. Plants used against cancer // Lloydia. 1970. - Vol 33. № 1, p. 97-194; 1971. Vol. 34. №1. P. 103-160.

15. Nikolov S., Panova D., Zareva T. S. Polphenol substances in Mespilus germanica leaves// Problem farmacyi, 1981. Vol. 9. P. 44-50.

16. Кушхов А.С. Очерки истории ботанических исследований в КБАССР. Нальчик: Эльбрус, 1968. 147 с.

17. Мушмула германская в горных лесах Центрального Предкавказья / М.Н. Фисун, Е.М. Егорова, М.Р. Долгиев [и др.] // International agricultural journal. 2019. № 4. С. 22.

18. Trimble Geomatix Office. User manual / Trimble Navigation limited / USA. 2001. - P. 144-147.

19. Утехин В.Д. Продуктивность растительности лесостепи Средне-Русской возвышенности // Биологическая продуктивность и круговорот химических элементов в растительных сообществах. Л.: Наука, 1971 
20. Фисун М.Н., Маммеев Х.С., Сарбашев А.С. Растения горной флоры для многоцелевого хозяйственного использования // Нетрадиционные природные ресурсы, инновационные технологии и продукты: сб. научн. трудов. Вып. 7. М.: РАЕН. 2003. C. 63-66.

\section{References}

1. Prirodno-klimaticheskie resursy Ingushetii. Nal'chik: El'-Fa, 2002. 224 s.

2. Gudkovskij V. A. Problemy i perspektivy obespecheniya svezhimi fruktami i povysheniya sostoyaniya zdorovyh lyudej / Istoriya, sovremennost' i perspektivy razvitiya sadovodstva Rossii. M., 2000. S. 38-45.

3. Kancalieva Z.L. Dikoplodovye rasteniya gornoj zony Central'nogo Predkavkaz'ya. M.: ANZ, 2009. S. 42-43

4. Koncepciya ustojchivogo razvitiya sel'skih territorij Rossijskoj Federacii na period do 2020 goda: utverzhdena rasporyazheniem Pravitel'stva RF ot 30 noyabrya 2010 g. № 2136-r // Informacionno-pravovoj portal GARANT.RU. Rezhim dostupa: http://baze.garant.ru/2073544.

5. Vitkovskij V.L. Plodovye rasteniya mira. SPb., M., Krasnodar: Lan'. 2003. 592 s.

6. Zhukovskij P.M. Kul'turnye rasteniya i ih sorodichi. L.: Kolos, 1971. 751 s.

7. Jamal T., Gets D. Collaboration theory and community tourism planning // Annals of Tourism Research. № 22. - 2009. P. 144-147.

8. Asadov K.S. Dikorastushchie plodovye derev'ya i kustarniki severo-vostochnoj chasti Azerbajdzhana // Rastitel'nye resursy. T. 15. Vyp. 4. 1979. S. 527-531.

9. Beni M.C. Polinica e Estraegia do desenvolvimento regional: planejamento integrado e sustentavel do turismo // Turismoem Analise. №10. - 1999. p. 216 - 218.

10. Rastitel'nye resursy SSSR: cvetkovye rasteniya, ih himicheskij sostav, ispol'zovanie; Semejstva Hydrageacae - Haloragacea. L.: Nauka. 1987. 328 s.

11. Mc Kinion J.M. Dinamic simulation: a positive feedback mechanism for experimental research in the biological sciences/ Agricult. Syst.- 1980. - V. 5. № 4. - P. 72-74.

12. Rabotnov A.T. Fitocenologiya. M.: MGU, 1985. $296 \mathrm{~s}$.

13. Alexander M. Soil microbiology in the next 75 years: fixed, flexible or mutable. Soil science jornal. 1991. - V. 151- №1. P.186-192.

14. Hartwell I.L. Plants used against cancer // Lloydia. 1970. - Vol 33. № 1, p. 97-194; 1971. Vol. 34. №1. P. 103-160.

15. Nikolov S., Panova D., Zareva T. S. Polphenol substances in Mespilus germanica leaves// Problem farmacyi, 1981. Vol. 9. P. 44-50.

16. Kushkhov A.S. Ocherki istorii botanicheskih issledovanij v KBASSR. Nal'chik: El'brus, 1968. $147 \mathrm{~s}$.

17. Mushmula germanskaya v gornyh lesah Central'nogo Predkavkaz'ya / M.N. Fisun, E.M. Egorova, M.R. Dolgiev [i dr.] // International agricultural journal. 2019. № 4. C. 22.

18. Trimble Geomatix Office. User manual / Trimble Navigation limited / USA. 2001. - P. 144-147.

19. Utekhin V.D. Produktivnost' rastitel'nosti lesostepi Sredne-Russkoj vozvyshennosti // Biologicheskaya produktivnost' i krugovorot himicheskih elementov v rastitel'nyh soobshchestvah. L.: Nauka, 1971

20. Fisun M.N., Mammeev H.S., Sarbashev A.S. Rasteniya gornoj flory dlya mnogocelevogo hozyajstvennogo ispol'zovaniya // Netradicionnye prirodnye resursy, innovacionnye tekhnologii i produkty: sb. nauchn. trudov. Vyp. 7. M.: RAEN. 2003. S. 63-66. 